\title{
LUT
}

University

\section{The timing of internationalization - Drivers and outcomes}

Ciravegna L., Kundu S.K., Kuivalainen O., Lopez L.E.

This is a Final draft version of a publication

published by Elsevier

in Journal of Business Research

DOI: $\quad 10.1016 /$ j.jbusres.2018.08.006

Copyright of the original publication: (c) 2018 Published by Elsevier Inc.

Please cite the publication as follows:

Ciravegna, L., Kundu, S.K., Kuivalainen, O., \& Lopez, L.E. (2018) "The timing of internationalization - Drivers and outcomes", Journal of Business Research, Advance online publication. https://doi.org/10.1016/j.jbusres.2018.08.006

This is a parallel published version of an original publication. This version can differ from the original published article. 
The timing of internationalization - drivers and outcomes

Ciravegna L., Kundu S.K., Kuivalainen O. \& Lopez L.E.

\section{This is a pre-print / an Author's Original Manuscript (AAM) of an article published by Elsevier in Journal of Business Research. Please cite the published article:}

Ciravegna, L., Kundu, S.K., Kuivalainen, O., \& Lopez, L.E. (2018) "The timing of internationalization - Drivers and outcomes", Journal of Business Research, Advance online publication. https://doi.org/10.1016/j.jbusres.2018.08.006

Luciano Ciravegna

King's College, University of London, The Strand, London, WC2R 2LS, United Kingdom

\& INCAE Business School, Apartado 960-4050, Alajuela, Costa Rica

Sumit S. Kundu

College of Business Administration, Florida International University, 345 B Ryder Business Building, 11200 SW 8 Street, Miami, FL 33199, USA

Olli Kuivalainen

Lappeenranta University of Technology, School of Business and Management, POB 20, 53851 Lappeenranta, Finland

\& Alliance Manchester Business School, the University of Manchester, Booth Street East, Manchester M13 9SS, United Kingdom

Luis E. Lopez

INCAE Business School, Apartado 960-4050, Alajuela, Costa Rica 


\title{
The timing of internationalization - drivers and outcomes
}

\author{
Ciravegna L., Kundu S.K., Kuivalainen O. \& Lopez L.E.
}

\begin{abstract}
Competing theories explain the timing of internationalization and its implications. In this study, we propose that the timing stems from complex combinations of drivers, and provide a typology of strategic types of internationalization in relation to these drivers: entrepreneurial, serendipitous, and strategic internationalization. We discuss how these strategic types affect the subsequent outcomes of internationalization. Strategic internationalizers choose markets and entry modes using economic rationale, often becoming multinational enterprises. Entrepreneurial internationalizers expand in ways that mirror entrepreneurial features, which may lead them to become multinationals, change business models, or continue expanding within their region. Serendipitous internationalizers may not be ready for international expansion, and may deinternationalize after an initial spurt, or continue a learning process and grow as exporters. We study the internationalization strategy of information technology exporters from Costa Rica.
\end{abstract}

Keywords: Timing of internationalization, multi-nationalization, outcomes of internationalization, mixed methods, Latin America, Costa Rica 


\section{Introduction}

When should a firm expand internationally and what are the consequences of the timing of international expansion? Why do some firms internationalize early and some late? Two sets of competing theories stemming from different disciplines seek to address these questions, pointing to factors related to the firm, the entrepreneur, and the market. The first set draws upon the resource-based view of the firm to explain when and the implications of firms going abroad and mainly link to the strategy and international business literature (Cavusgil \& Knight, 2015; Hennart, 2014; Knight \& Cavusgil, 2004). The second set, draws upon entrepreneurship literature and looks at motives and behaviors of entrepreneurs and how they influence a firm's strategy (in particular, internationalization timing) and its subsequent development (Andersson, 2000; Sommer, 2010). The third set focuses on market factors such as competition or customer demand for a particular product or service (Leonidou, Katsikeas, Palihawadana, \& Spyropoulou, 2007), and draws on economics and strategy.

The rapid increase in the sheer number of small firms internationalizing early in their lifecycle has heightened the interest in the phenomenon of early internationalization and the drivers behind the behavior. Early internationalizing firms ${ }^{1}$ have often been compared to the traditional, slow-paced internationalization process, which resembles the Uppsala model (e.g., Bell, McNaughton, Young, \& Crick, 2003; Johanson \& Vahlne, 1990).

Further, some believe that early internationalization can be an antecedent of positive performance outcomes for many firms (e.g., Autio, Sapienza, \& Almeida, 2000; Moen \& Servais, 2002). The empirical evidence on the outcomes of early internationalization remains scant, thus, according to Cavusgil and Knight (2015), "tracking longer term performance (...) should be intriguing and rewarding” (p. 13). Some empirical evidence on longer-term performance of early internationalized firms exists (e.g., Kuivalainen, Sundqvist, \& Servais, 2007; cf. the review of Casillas and Acedo; 2013). For example, Kuivalainen, Saarenketo, and Puumalainen (2012) found that many firms following the so-called 'true born global strategy' were able to increase their international presence either independently or through mergers and acquisitions. The comparison between early and late internationalizers is difficult. For example, the terms born global or international new venture appear in a large body of research, but without a clear agreement on their definitions in terms of measurement or their implications on performance (Kuivalainen et al., 2012; Verbeke \& Ciravegna, 2018).

There are several possible outcomes to consider with regard to the consequences or implications of the timing of internationalization (see, e.g., Kuivalainen et al., 2012). The response to an overarching question, 'what happens after early internationalization' (see, Casillas \& Acedo, 2013; Kuivalainen et al., 2007; Zahra \& George, 2002), could be, for example, about increasing commitment in international markets by opening up new markets or establishing subsidiaries that could make a focal company a so-called "micro-multinational"-a process we define as multinationalization (e.g., Vanninen, Kuivalainen, \& Ciravegna, 2017). Some firms

\footnotetext{
${ }^{1}$ In this paper we use the terms "early internationalizing firms" or "early internationalizers" — often called bornglobals and international new ventures (see e.g. Cavusgil \& Knight, 2015; Coviello, 2015)_to describe those firms that internationalize soon after founding. We focus on the timing of internationalization by considering the time that elapses between a firm's inception and its first foreign entry.
} 
may also de-internationalize, or retreat toward their domestic market after an early spurt of foreign sales (Benito \& Welch, 1997) and some might internationalize immediately after inception, then retrench inward, and perhaps at a later stage again become international (see, e.g., Bell et al., 2003; Casillas \& Acedo, 2013). Overall, there can be several outcomes for internationalization's timing (Kuivalainen et al., 2012) but we have limited information of the reasons leading to different outcomes. As a result, it is useful to build theories and frameworks that can explain the phenomenon (cf., e.g., Cavusgil \& Knight, 2015; Jones, Coviello, \& Tang, 2011; Oviatt and McDougall, 1994).

Consequently, we address two main research questions: (1) what are the drivers of the timing of internationalization and (2) do they form specific strategic types of internationalization linked to the outcomes of the timing? We study both the drivers and outcomes of early (and late) internationalization, contributing to the literature on international business and research on emerging economies. Furthermore, by using an integrated multi-theoretical framework to study the phenomenon, we formulate and assess a set of different types of drivers explaining the timing of internationalization. We provide a meaningful interpretation of these sets, which enables us to suggest a categorization or typology of internationalization timing drives and their related evolutionary implications for the firms. We thus address a research gap that exists because, in spite of numerous publications focusing on early internationalizing firms, only a few studies examine what happens to the observed firms after their initial internationalization (Casillas \& Acedo, 2013; Cavusgil \& Knight, 2015). Our research is more exploratory but our aim is to provide a comparative base for studies focusing on different types of internationalizing firms in relation to the antecedents of timing of internationalization, and the consequences of both drivers and actual timing.

Starting with the existing literature, we identify perceptual and non-perceptual variables with regard to the timing of internationalization and develop a parsimonious typology of internationalizers on the basis of their drivers. We examine in-depth qualitative data collected over seven years during the initial data collection to explore the implications or outcomes of the timing of internationalization and find that several of the firms examined had become multinational enterprises (MNEs), while a few had ceased to operate. We find that perceptional and motivational variables, in addition to the more tangible resource, customer, and competitor related variables (which we could call 'non-perceptional'), confirm typology of proclivity to early internationalization that may be consistent and recurring. We can categorize the two sets of drivers linked to internationalization occurring rapidly after inception as "entrepreneurial internationalization" and "strategic internationalization," whereas a third set of drivers led to relatively late "reactive internationalization.” With such typology, and with the unique ex-post re-evaluation of firm performance over time, we shed light upon the possible outcomes of early internationalization undertaken by firms; for example, whether the drivers seem to lead the firms toward a more domestic, regional, or global "path" in their internationalization process, with different attitudinal outlooks and with entrepreneurs and their attitude toward internationalization at the very center.

The timing of internationalization is also particularly relevant for companies from small economies where the options of expanding domestically are limited. This is the empirical context we examine focusing on Costa Rican information technology (IT) producers. Costa Rica is 
interesting because it is the top exporter of IT in Latin America, often used as a benchmark in the region (Ciravegna, 2012). Thus, studying Costa Rica's IT exporters addresses an empirical gap, as consistent with the objectives of the Strategic Management in Latin America Conference linked to this Special Issue of the Journal of Business Research (Brenes, Camacho, Ciravegna, \& Pichardo, 2016).

\section{Timing of internationalization, drivers, and consequences}

According to Welch and Luostarinen (1988), internationalization is "the process of increasing involvement in international operations” (p. 36). Some firms internationalize earlier than others; empirical studies have provided a range of, at times, contradictory explanations to such heterogeneity in internationalization timing (Coviello, 2015; Hilmersson \& Johanson, 2016). Some studies suggest that the timing of internationalization depends on firm-level resources (internal and/or external, e.g., Mathews \& Zander, 2007). Other scholars focus on the background and characteristics of the entrepreneur (e.g., Andersson, 2000; Dimitratos, Johnson, Plakoyiannaki, \& Young, 2016). Often, combinations of a number of variables from different literature streams occur. For example, Oviatt and McDougall (2005) propose a model that elucidates the timing of internationalization by looking at technology factors, competition, and opportunities identified.

Oviatt and McDougall (2005, p. 540) define international entrepreneurship as "the discovery, enactment, evaluation, and exploitation of opportunities-across national borders-to create future goods and services.” This definition contains not only behavior but also the components that increase such behavior-a sequence of causality starting at discovery, proceeding through enactment and evaluation, and ending at exploitation. Opportunities in the international business literature are often situations where a new foreign market entry is a possibility (e.g., Johanson \& Vahlne, 2009; Reuber, Dimitratos, \& Kuivalainen, 2017) and, as pointed out above, there may be numerous drivers behind this decision and the international entrepreneurship process in general, including the entrepreneurs' perceptions and motives.

\subsection{Entrepreneurs' perceptions and the timing of internationalization}

Several studies in the international entrepreneurship literature (e.g., Andersson, 2000; Dimitratos et al., 2016; Oviatt \& McDougall, 2005; Zahra, Korri, \& Yu, 2005; see also Shepherd \& Patzelt, 2017 about decision-making) highlight entrepreneurs or managers and their role as a catalyst for internationalization. Reid (1981), in his early study on decision-makers and export entry and expansion, emphasized the role of managerial knowledge, attitudes, and motives. However, the role of perceptions and motives lacks sufficient examination in the study of small firms' internationalization, in spite of its potential impact on firm strategy and development (Coviello, 2015; Freeman \& Cavusgil, 2007).

The exporting literature suggests that the risk associated with entering new markets is an important determinant in the internationalization decision (Freeman \& Cavusgil, 2007; Dimitratos et al., 2016; Sommer, 2010; Wiedersheim-Paul, Olson, \& Welch, 1978). Risk is also a central concept in the entrepreneurship literature (Oviatt \& McDougall, 2005; Shrader, Oviatt \& McDougall, 2000; Terjesen, Hessels, \& Li, 2016). Risk taking is a part of the entrepreneurial 
orientation construct and relates to the speed, scope, and performance consequences of internationalization (Javalgi \& Todd, 2011; Kuivalainen et al., 2007). If an entrepreneur or manager is more willing to take risks, he or she is more likely to internationalize early - even though obstacles such as liabilities of foreignness and outsidership exist (cf. e.g. Johanson \& Vahlne, 2009). Based on this type of reasoning, the focal study includes risk perception as a driver of the timing of internationalization

Second, an entrepreneur's perception of the profitability of international markets may drive firms' internationalization (Ogram, 1982). However, the ways in which profitability affects internationalization decisions remain disputed (Ojala, 2009; for a recent review of international entrepreneurship-performance relationships see Schwens, Zapkau, Bierwerth, Isidor, Knight, \& Kabst, 2017). To contribute to this debate, we examine the entrepreneur's perception of the profitability of export markets as a driver of the timing of internationalization.

Third, the size of the domestic market should influence internationalization strategy, for example, deciding when and how to expand abroad (see, e.g., Moen \& Servais, 2002).

Nonetheless, empirical evidence about the effects of domestic market size remains disputed, with studies showing that even small economies' firms internationalize late or stay domestic (Lopez, Kundu, \& Ciravegna, 2009).Consequently, we study how entrepreneurial perceptions of opportunities in their domestic market interact with other drivers to define internationalization typologies.

\subsection{Capacity, clients, and competitors and the timing of Internationalization}

Internationalization or exporting may arise for different reasons, such as the desire to exploit underutilized capacity (Leonidou, 1995; Westhead, Wright, \& Ucbasaran, 2001), which one can analyze from the resource-based view perspective. Whether a firm has the resources to operate abroad or not affects the internationalization process. For this reason, having underutilized capacity serves as a driver in our model.

Second, firms may pursue several strategic objectives related to the competitive situation, for example, entering a new market before competitors or reacting to incumbents' entry into the domestic market (Autio et al., 2000). Drawing from Porter (1998), the market often shapes firms' strategy, that is, how they relate to competitors. We thus include reaction to competitors as one of the drivers of early (or late) internationalization (see also Johanson \& WiedersheimPaul, 1975; Leonidou et al., 2007; Malhotra, Agarwal, \& Ulgado, 2003).

The discovery of international business opportunities is not only a proactive but also a reactive process brought about through serendipity (such as unsolicited orders) and cannot be anticipated in advance (Chandra, Styles, \& Wilkinson, 2009; Kontinen \& Ojala, 2011). We examine unsolicited orders in the model, defining them as non-perceptual drivers - as this would be a reactive activity to a demand of a new possible foreign customer - that can affect the timing and geographical scope of internationalization (Hennart, 2014).

\subsection{Implications or outcomes of the timing of internationalization}


As pointed out above, there is still a surprisingly small number of empirical studies that report the outcomes of the timing of internationalization more generally (see, e.g., Casillas \& Acedo, 2013; Zahra, 2005; for some exceptions see, e.g., Kuivalainen et al., 2012; Mudambi \& Zahra, 2007). Also as pointed out earlier, this is an area where further research is required (Cavusgil \& Knight, 2015). Furthermore, one can study the outcomes from several perspectives. One possibility is to focus on survival (e.g., Mudambi \& Zahra, 2007) and/or ownership changes; that is, if a firm has survived and stayed independent and had an independent offering, or another firm had taken it over (Kuivalainen et al., 2012). In the case of internationalization presence, a noteworthy issue is the possible increase in internationalization (e.g., multi-nationalization, see Vanninen et al., 2017 for born micro-multinationals; Monaghan \& Tippmann, 2018) or decrease in international presence. The latter is about the reverse patterns that underlie deinternationalization and withdrawal from international markets (see, e.g., Benito \& Welch, 1997). In the case of knowledge-intensive small and medium enterprises (SMEs), 'small scale' initial early internationalization often leads to de-internationalization, (e.g., Kuivalainen et al., 2012). However, after de-internationalization, a firm may eventually re-internationalize, which Welch and Welch (2009) defines as "withdrawal from inward and outward international operations by a company before subsequent international re-entry” (p. 568) and may be an outcome when studying the whole internationalization process from a longitudinal perspective. In summary, firms' internationalization often is not a linear, incremental, unidirectional pathway and a number of unique or even nonlinear patterns exist (e.g., Bell, McNaughton, \& Young, 2001; Vissak \& Francioni, 2013). The initial internationalization can lead to various outcomes such as 'stagnation,' where an international presence in relation to, for example, a number of markets and operation modes, would not change, or expansion using the same mode, or multinationalization, or retreat or failure.

As pointed out above, our approach in relation to the outcomes is exploratory; however, we focus on whether different internationalization typologies would have different implications for firms. It may be that different drivers such as proactive behavior based on perceptional factors would foster a more advanced learning strategy from international operations. Learning in general is a key aspect in the internationalization process (e.g., Johanson \& Vahlne, 1990, 2009) and should affect outcomes as well as initial internationalization. Figure 1 summarizes our research design. In our empirical study, we first build a typology of strategic types of internationalizing based on the described antecedent factors or drivers (either perceptional or 'non-perceptional') and then explore whether different sets of drivers of early (or late) internationalization lead to different outcomes.

INSERT FIGURE 1 HERE

\section{Methods}

\subsection{Data}

The first round of data collection occurred between 2007 and 2008. Our inclusion criteria were for the firms to be Costa Rican companies that were producers of IT goods. Information provided by the local Information Technology Producers' Association (CAMTIC, 2008) generated an updated list of firms. We collected data using a survey questionnaire and face-to- 
face interviews, followed by phone conversations to corroborate the information collected. Excluding firms where the founder/entrepreneur was not available for interview, we carried out face-to-face interviews at 29 firms (see Table 5), amounting to 70\% of the Costa Rican IT exporters at the time (Villalobos \& Monge-González, 2011). Firms in the sample saw average sales at the time of the study of $\$ 1.5$ million US\$, with a minimum of $\$ 45,000$ US\$ and a maximum of $\$ 6.4$ million US\$. The median sales were approximately $\$ 750,000$ US\$. Founders, whose educational background was, in most cases, technical—with computer and information systems engineering being the dominant backgrounds - appear in our sample. Interestingly, 10 firm founders also reported having earned an MBA. Three founders reported backgrounds in the social sciences.

\subsection{Drivers}

The first part of the study focuses on two groups of drivers of internationalization timing: first, drivers related to risk and profitability of internationalizing as well as the limited size of the domestic market according to the entrepreneur's perception; and, second, drivers related to the reception of unsolicited orders, the existence of underutilized capacity, and competition. Table 1 provides details about the drivers.

\section{INSERT TABLE 1 HERE}

\subsection{Second data collection: implications or outcomes of the timing of internationalization}

To examine the implications of early internationalization, we carried out a second data collection in 2017, approximately 10 years after the first fieldwork. We verified which firms were still operating by contacting all the firms in our initial sample by phone and/or email. We found that 21/29 firms were still active, and eight had ceased to operate under the same name. We then invited them to join us in a follow-up study. We conducted interviews with two key informants operating in the industry to acquire further information, and searched for secondary information in local archives, media outlets, and the local association of IT producers. We performed interviews with 10 entrepreneurs, founders of $8 / 29$ of the firms in our initial sample. In these interviews, the respondents elaborated on the processes and outcomes of their initial internationalization.

\section{Results}

We conducted a principal component analysis to identify typologies related to the motives of internationalization and their timing. Here we used the drivers explained earlier.

\subsection{Establishing entrepreneurial typologies}

We first establish entrepreneurial types based on firms' characteristics when they first internationalized. To do so, we reduced the six drivers or composites to three. In a second stage, we used clustering techniques to enhance the validity of the groupings by assessing whether, in fact, the factors uncovered loaded onto distinct entrepreneurial types. We used the entrepreneurial components or composites resulting from the principal component analysis as input to cluster the firms into entry types. Our two-stage approach involved the use of principal component analysis (PCA). PCA allows the use of orthogonal dimensions, which then facilitate 
the interpretation of resulting clusters. The use of a reduced set of components allowed a focus on the central relationships underlying different drivers. By using a two-stage approach, we were able to verify that clusters were homogeneous and clear. Table 2 shows the corresponding components for the set of variables of interest and the corresponding eigenvalues. The first three components together represent $61 \%$ of the variance. We performed PCA (Dunteman, 1989; Jolliffe, 1986) on standardized variables. Because one can perform PCA on either the correlation or the covariance matrix, we analyzed both. Because the relative sizes of the standard deviations of our variables were similar, we found no differences between the methods. We selected the first three principal components representing $61 \%$ of the variance in order to concentrate on the most important relationships in the data.

\section{INSERT TABLE 2 HERE}

We focus on the first three components: PC1, PC2, and PC3. PC1 and PC3 represent early entrants, whereas PC2 represents entrants that, within our sample, ${ }^{2}$ occurred relatively late. Although combined with different drivers, both PC1 and PC3 have a small market motivation for early exporting present. This is a predictable, yet relevant, finding to understand the internationalization of firms based in Latin America, because Latin American firms tend to be rather inward oriented, even when based in small countries, as other researchers have observed (Ciravegna, Lopez, \& Kundu, 2014). PC1 denotes young firms’ internationalization motivated by small home market size aligned with their perceptions of international business. ${ }^{3}$ It shows that there are entrepreneurs who do not consider early internationalization risky or unprofitable. There is no importance ascribed to exporting as just a way of making use of underutilized capacity or reacting to competitors. PC1 shows the possible presence of unsolicited orders, which could signal entrepreneurs with a given set of attitudes who are able to take opportunities as they come. That small domestic markets and perceptions of risk and profitability motivate early internationalization corroborate previous studies of international entrepreneurship (Acedo \& Jones, 2007; McDougall \& Oviatt, 2000; Shrader et al., 2000; Zahra, Neubaum, \& Huse, 1997). We could call this composite, PC1, the "entrepreneurial internationalization" as this is the type of internationalization that is primarily driven by the entrepreneur and his or her perceptions. The prevailing perceptions lead entrepreneurs to take advantage of opportunities and to consider foreign expansion profitable and not risky regardless of whether it may entail investing in extra capacity. The entrepreneurs in this group emphasized their personal commitment to international expansion and their willingness to face its risks with phrases such as "it was going to be difficult, but it was an important target for me"; "I was not sure about the

\footnotetext{
${ }^{2}$ As the software industry is a global, high-technology industry, we can expect that many firms internationalize relatively early in comparison to other industries.

${ }^{3}$ Firm no. 10 of PC1 is an outlier, that is, a firm that, in spite of internationalizing for reasons linked mainly to the perceptions and attitudes of the entrepreneur, actually made the decision to internationalize quite late. The explanation, found via qualitative information, is that the firm was founded by two entrepreneurs who had a conflict about more than just internationalization. This conflict put the firm in a standby situation for several years, as key decisions could not be made without their agreement. Eventually, one of the two entrepreneurs left the firm, and the one remaining (whom we interviewed) decided to internationalize 13 years after its founding. This outlier case confirms the main results of the model, i.e., that PC1 decide when to internationalize because of international business risks, profitability, and small market size, and that unless there are conflicts between the decision makers, they internationalize at a young firm age.
} 
potential profits to be made, but I wanted to try it.” Some admitted that not everybody in the firm agreed with their insistence on internationalizing, questioning whether it was worth the risks, yet they pushed forward anyway. The founder of BETA (a firm we discuss in the following section of this study), for example, commented: “my team was very scared. I was scared. But I was sure that the benefits from it would materialize. Even if the risk was high, I insisted, and convinced the senior people in my firm."4

The second composite, PC2, shows that the time to first export happens relatively late, as compared with other firms in the sample. Perceptions of risk and profits are not relevant drivers, and entrepreneurs do not consider their home markets to be too small. This composite is one where entrepreneurs internationalize reactively because they receive unsolicited orders and have the capacity to respond to them (Table 3). The argument is consistent with the idea that serendipity may play a role in an internationalization decision (Ellis, 2011; Kontinen \& Ojala, 2011). We interpret this composite as "serendipitous internationalization.”

PC3 denotes entry at a relatively young firm age. Here, entrepreneurs' perceptions of risk related to going abroad does not hinder internationalization. The limited opportunities available in a small home market are a key determinant in PC3. This type of behavior is, to a certain extent, surprising since risk taking characterizes early internationalization (Shrader et al., 2000; Terjesen et al., 2016). This composite reflects a more strategic approach to internationalization, where firms strategize taking into account the risks of their decisions, including entering new markets, and attempt managing such risks (Johanson \& Vahlne, 1990; Oviatt \& McDougall, 1994). Our interviews illustrated that the firms that fit categorization within PC3 specialize in niche products developed with the global market in mind. One of the founders of SIGMA, explained: "It was our plan from the start to target international markets: we had to find the resources to do so, and we knew it was not going to be easy, but we had to risk it, Costa Rica was not large enough for what we had in mind." Notably, two of the firms in PC3 invested in fully owned operations abroad to be closer to their clients, thus moving quickly from being new companies to being early internationalizers, to being young multinationals. We interpret this as "strategic internationalization."

To validate whether we could tie these composites to entrepreneurial types, we proceeded to the second stage of our analysis and clustered the firms on the basis of their scores on the three principal components described. We used clustering techniques as described in Hartigan (1975) and in Aldenderfer and Blashfield (1984). Table 3 shows cluster means with clustering made using firm scores in the three principal components with eigenvalues greater than 1 .

\section{INSERT TABLE 3 HERE}

As Table 3 shows, each cluster loads primarily onto one of the composites previously unveiled, which gives us confidence in that the strategic types of internationalization in the typology correspond to our interpretations and that there are empirical occurrences related to the components. This typology helps us understand how perceptional and non-perceptional variables coalesce to establish firm types with different drivers and different speeds associated with

\footnotetext{
${ }^{4}$ Quotes are from interviews and names are withheld for privacy reasons.
} 
internationalization. Marketing (Dowling and Midgley, 1988) and international SMEs (Hagen, Zucchella, Larimo, \& Dimitratos, 2017) have a history of using this two-stage approach.

\subsection{Outcomes - the implications of internationalization timing}

The follow-up fieldwork we undertook in 2017 found that only 21/29 firms were still operating. Out of those no longer active, two had been purchased and incorporated into larger foreign MNEs, two changed their name and business model (but were still led by the same founder), and the other four had closed.

\section{PC1: Entrepreneurial internationalization}

We found follow-up information on four firms that internationalized early as described by the PC1 composite or strategic type we call entrepreneurial internationalization. The first, ALFA, ${ }^{5}$ a firm that internationalized through an aggressive foreign sales campaign where the entrepreneur leveraged his personal networks and those of the sales force he hired, cemented its international exposure through time. Between 2009 and 2017, it opened sales support subsidiaries in Mexico, Bolivia, and Argentina in order to provide better client support and expand its presence in these markets. It then moved its headquarters from Costa Rica to one of its key markets, partly because it was already employing more people there, and partly to signal its "localization" in the most strategic market for them. From the start, early internationalization provided the firm with the tools it needed to manage clients in multiple markets. When it moved past its first export-driven internationalization, the founder decided to expand further into foreign markets. In order to do so, he opened subsidiaries in the markets where the firm already had at least one client. He noted, "we learned a lot by going abroad early...it was a learning by doing process, we did mistakes, and we learned." This is a case where a first aggressive export-driven phase developed into a consolidation phase, which then led to multi-nationalization. The entrepreneur confirms that it was not initially his plan to open subsidiaries, but that it became clear to him that remaining only as an exporter limited future growth prospects, and thus changed his mind. He points out that he had already made an effort to hire foreigners and people with international experience, which became useful when setting up the first subsidiary. Notably, this is a firm that internationalized regionally first and subsequently to a broad range of markets. This firm moved from having a high export intensity, to reporting a low export intensity because of using subsidiaries to process sales abroad.

Another case is that of BETA, a firm that internationalized early focusing only on markets located near Costa Rica, in the same region, but also in the same sub-region of Central America. The firm again internationalized early, taking advantage of the broad network of its founders, and acquired clients in most of the neighboring countries. It gradually expanded into other markets in Latin America, again confirming that the experience was challenging but very useful in that it pushed the firm to develop products suitable for different markets from the start as opposed to adapting local products to foreign markets. Early internationalization also generated challenges related to contracts and different regulatory conditions that again helped the firm become more flexible and adaptable. In 2013, the firm opened a subsidiary in a lower-cost country than Costa Rica, where it relocated a large share of its nonstrategic operations. This is an

\footnotetext{
${ }^{5}$ Real name witheld for reasons of privacy. The same policy is followed in the case of all the case firms.
} 
interesting case where early internationalization helped the entrepreneur and the firm to acquire information about international markets, which resulted in the firm becoming a multinational for cost-saving reasons or efficiency-seeking foreign direct investment, according to its founder.

GAMMA, the third company that internationalized according to PC1 had ceased to exist under the same name. It exported all of its output until it was operational. The firm internationalized early and aggressively, again because of the personal attitudes of the founder regarding international expansion. "I was perhaps a bit reckless, but I pushed for this to be an international business from the start, it was what I wanted to do, and I was ready to take risks for it.” The firm then received an investment from one of the largest American MNEs in the IT industry, which helped it expand and find new clients. The firm opened a subsidiary in Europe in order to cater to a local client then established a partnership with a European IT firm. The European partner, after two years of collaboration, purchased the Costa Rican firm andchanged the name of the firm. The Costa Rican entrepreneur funded other businesses in Costa Rica.

DELTA represents a firm that went through a different evolutionary trajectory. After early internationalization, it went through a period of stagnation and retreat from international markets. Subsequently, it completely changed its business model and name-becoming a de facto different firm. It moved from being primarily a developer of business software to a firm specializing in data centers and data storage and management. It invested in three new installations for a total of more than 15 million US\$, and focused on a smaller range of more strategic markets. This is a firm that started internationalizing in an entrepreneurial manner driven by the founders' ambition, initially targeting clients in the region, then outside of Latin America. The international exposure pushed the firm to plan its further expansion in a way that is consistent with PC3, in other words, more similar to that of a larger firm developing its new services with specific markets and clients in mind using a clear strategic plan. Its sales are now mostly to foreign clients, though it retreated from a few Latin American markets due to insufficient demand. It did not open cost-saving subsidiaries because its business has moved from being labor intensive (programming and software development) to being capital intensive. It did not open market-seeking subsidiaries because it manages its services remotely and does not apparently require or benefit from on-site presence near clients.

\section{PC2: Serendipitous internationalization}

MUDI, a firm that internationalized reactively, did so because it responded to unsolicited orders. After a brief adventure selling internationally, the firm retrenched into its (small) domestic market. MUDI is still active but has reduced its workforce by 50\% since 2009 and has failed to invest in new installations and new online platforms and websites. Its list of clients has remained the same, pointing to a failure to grow. Although it was impossible to obtain specific information, we were able to discern that the firm has not hired in several years, and that it has failed to take part in domestic fairs and IT-related events in recent years, all of which are signs of distress. The fate of the firm highlights that one should not interpret internationalization, per se, as a sign of successful international expansion or as the the trigger of international success. In this, our findings support the study by Kuivalainen et al. (2012), who found that knowledgeintensive SMEs following a traditional internationalization pathway were more likely to achieve “only mediocre success in their internationalization, or even to de-internationalize” (p. 383). 
Further, firms may internationalize because of serendipity, rather than because they necessarily have the capabilities and resources to operate internationally. JUDI, another firm that internationalized responding to an unsolicited order (having the capacity to do so) (PC2), which we were able to contact directly, not only continues to operate, but has since expanded into new foreign markets and now exports a large portion of its output. Its founder commented: "I had no plans to sell abroad. Then the order came, and we started working on it. It was a very unpredictable event, which changed completely our attitude with regards to the domestic market: before we thought we could be fine at home, after, we understood that there was a whole world of opportunities, of potential partners, clients, and jobs to do if we continued operating abroad." He emphasized that the first experience of export was fundamental for them-it changed their attitudes and stimulated them to look for more opportunities abroad. Additionally, the exposure to competition in their first export market forced them to improve their services, in particular the way in which they marketed their product and their customer support. The latter case illustrates that internationalization can transform a firm into a more internationally oriented venture, even when it occurs reactively and relatively late. This is especially true if internationalization provides a platform for improvement for the firm, for example, stimulating a learning process that leads to better products and services. This type of internationalization resembles the bornagain global firms of Bell et al. (2001; 2003). We can represent this case as a transformation from PC2 to PC1, whereby entrepreneurs, by internationalizing, change their attitude toward the domestic market, risks, and profits, and engage in aggressive international expansion.

\section{PC3: Strategic Internationalization}

ETA internationalized quickly and intensively, selling most of its output abroad from the beginning. The firm had a sales, marketing, and client support subsidiary in the United States, its largest market, from the inception, taking advantage of the fact that one of the founders was a seasoned Costa Rican Silicon Valley professional. For this reason, it never reported exports from Costa Rica, selling all its output from the U.S. subsidiary itself. Since 2009, the firm continued to grow and eventually opened other two subsidiaries in low-cost countries in order to manage rising labor costs in Costa Rica. This is a case of early internationalization occurring via multinationalization, which thus differs from the others and is more consistent with evidence on MNEs (cf. e.g., Vanninen et al., 2017). The founder explained: "It was never a plan to sell here [in the domestic market]. This business was planned with the U.S. market in mind, and we developed it following that plan.” In the case of ETA, its export intensity appears low because it sells all of its output through its foreign subsidiary, which manages customer relations as well as sales and marketing.

SOFT, another firm that internationalized through a planned process, and disregarded whether it considered it risky or not, went through a period of accelerated growth between 2000 and 2010 thanks to its sales to Microsoft. Microsoft also invested in the firm, helping it to further expand and to acquire new international clients. The experience drove the firm to withdraw from Costa Rica and nearby regional markets, focusing instead on the U.S. market targeting mainly large clients. In 2014, SOFT launched a new range of products for migration to cloud and mobile platforms, which helped it to achieve almost 60\% growth in its average annual sales. It then established a collaboration with a large U.S.-based client, whose CEO had been a vice-president of Microsoft when the latter began collaborating with SOFT. The U.S. client purchased SOFT in 
2016, and incorporated it in the United States but expanded its Costa Rican operation. This is a case where from the beginning the firm planned to sell internationally due to the niche nature of its product, and did so early and aggressively, thereby acquiring visibility and contacts that supported its further growth and expansion.

SIGMA is a firm that developed a niche product for banking security, which soon after its foundation sold in several markets in Latin America. It briefly became one of the fastest growing firms in Costa Rica during the 2005-2007 time period. Its founders, an academic and an inventor, failed to agree on how to manage the firm and eventually one of them, the academic who created the firm's product, left the firm and funded a competitor. Since then, SIGMA has stagnated, failing to renew its product line. It has retreated from some of its foreign markets, and although still operating, has failed to maintain its website and has not hired since 2011. The academic who funded the competing firm affirms that the initial international success was important for him in terms of having a more open-minded approach to where to market products, and facing the challenges of dealing with foreign clients, which, although being in the same region, had different negotiating customs and operated in a different regulatory structure. This is a case where early internationalization did not generate firm-level success, but did help the managerial experience of one of the founders, who now leads a highly internationalized business, selling roughly three quarters of its output abroad. He points out that he funded the first business to put his invention to use and his co-founder contributed the business experience to go abroad. When funding his second business, the academic had international markets in mind. His new firm, more internationalized from the start, has not yet opened subsidiaries.

\section{Discussion and conclusions}

In this paper, we studied a number of drivers of the timing of internationalization and its implications focusing on Costa Rican IT firms. Although our focal sets of factors are not exhaustive, we can show that drivers form specific strategic types of internationalization, and that these types provide a variety of outcomes. Based on our results, we propose that the timing of internationalization stems from complex combinations of theory-derived drivers, and provide a typology of strategic types of internationalization: entrepreneurial, serendipitous, and strategic.

\subsection{Theoretical implications}

We shed light on the drivers of internationalization, which appear in exporting research (e.g., Leonidou et al., 2007) but lack study in the empirical setting of Latin America. The findings can help to develop new research streams and guide how one can integrate different theories to explain the divergence in results found in existing empirical studies of early (or late) internationalization (Boso, Story, \& Cadogan, 2013; Jones et al., 2011). Empirically, we show that, although small domestic market size is an important driver, it does not per se explain that firms will internationalize early or intensively. Rather, one should see it as part of a more complex set of determinants of internationalization timing. We support the idea that multiple, complementary theoretical viewpoints are helpful to frame reality, which would help us to better understand the role of entrepreneur in international entrepreneurship and marketing. It has been found in the past that managerial cognition has an effect on decision-makers' strategic actions (Zahra et al., 2005). It is clear that the perceptions of managers and entrepreneurs may assess 
and determine the viability of entrepreneurial opportunities in international markets and their responses to these opportunities. Our findings corroborate earlier studies (see, e.g., Acedo \& Jones, 2007; Cavusgil \& Knight, 2015), and build on those by looking at outcomes beyond drivers leading to early or late internationalization.

In relation to the outcomes, small IT firms in general experience amplified risks and issues due to their resource constraints. Approximately one third of IT firms fail during their first four years (Ganesan \& Samii, 2016). We find that firms that internationalize reactively through responses to serendipitous events may very well engage in a one-off episode of international sales. Thereafter, they return to their domestic nature unless they can exploit unsolicited orders to improve the resources of the firm, and internationalization becomes a strategic objective (Table 4). On the contrary, the firms that have a strategic plan for internationalizing corroborate the idea that entrepreneurs may act as rational managers and expand abroad because of strictly economic motives. This can include limited business opportunities in the home market, and, in particular, the location of demand for the specific product they make, a point Hennart (2014) explains in detail. Finally, the firms that internationalize because the entrepreneur perceives it as not being risky and a profitable avenue to pursue, may develop into multinational firms if the internationalization process moves from an aggressive, risk-taking venture into a more planned and strategic choice, migrating from PC1 type to PC3 type in terms of our typology. Otherwise, enthusiasm for taking risks and facing internationalization challenges may not be sufficient, even after early internationalization, to sustain firm growth.

\section{INSERT TABLE 4 HERE}

In terms of outcomes, it is useful to have a look at geographic scope. It is the firms that plan from the start to be international that tend to specialize in niche products (PC3), requiring that international sales reach critical mass. They tend to target markets outside of Latin America, as consistent with the economic reasons that drive their internationalization, and to choose countries for their international operations depending on economic rationale, selecting countryspecific advantages that match their firm resources, as per internalization theory (Verbeke \& Kano, 2016). They tend to invest in the United States to serve its large market, and to access its strategic resources - such as partnerships with specialized service providers and research centers - while they invest in low-cost locations to perform the most labor-intensive functions. The entrepreneurial internationalizers (PC1) tend to focus on neighboring countries-precisely because in these cases the entrepreneur is central to the internationalization process, using his or her own personal resources, in particular social ties, to find clients and business opportunities abroad. This means that often such opportunities materialize near home, even if neighboring countries may not be large economies (Ciravegna et al., 2014). Here one could see linkages to the Uppsala model type of internationalization as well (cf. e.g., Johanson \& Vahlne, 2009). This is naturally more evident in PC2 as the firms that internationalize reactively (PC2) also tend to target regional markets.

Finally, in terms of a firm's evolution, these firms experience cycles of learning by doing, whereby they may de-internationalize, target different markets, and/or experiment with multiple entry modes (Bell et al., 2001, 2003; Kuivalainen et al., 2012). The entrepreneurs of PC1 may also change their business model and sell, exiting the business altogether, which is again 
consistent with their importance in defining firm strategy. Serendipitous internationalizers seem to either continue in an evolutionary manner toward internationalization, or retrench domestically. Strategic internationalizers naturally expand to search the markets they initially targeted, which may lead to becoming MNEs quite early (Vanninen et al., 2017; Monaghan \& Tippmann, 2018). Even in a case of the strategic execution of planned internationalization, disagreements in top management may lead to stagnation-as our SIGMA example demonstrates. In short, any small internationalizing firm may fail, whether because it overstretched its capacity, perhaps by expanding due to entrepreneurial attitudes not matched by resources, or because new opportunities to sell abroad failed to materialize, or because of other unplanned events such as changes in markets or internal issues. As we discuss here, in all cases the initial drivers of internationalization timing guide the way in which firms expands. For this reason, firms that internationalize early because they plan to do so, and because there are clear economic reasons for doing so, may be better suited to survive the challenges of international markets and develop into MNEs than firms that internationalize only in response to unplanned events, or firms that rely excessively on the attitudes and resources of the entrepreneur (see, e.g., papers that look at decision-making and cognition such as Zahra et al., 2005). Another interesting theoretical insight is that internationalization changes firms and entrepreneurs, for example, by providing opportunities to acquire new knowledge about products and markets. Thus, the firms that internationalize without a clear strategic plan, either for entrepreneurial attitude-related reasons (PC1) or for reactive reasons (PC2), may change in due processentrepreneurs that pushed internationalization may find different opportunities and change business models, seek new investors, sell their firms, or engage in different entry modes. They may change from a personalized internationalization, based on entrepreneurial resources and attitudes, to a more a planned, strategic approach, or migrate from PC1 to PC3. Similarly, the entrepreneurs that internationalize only because they reacted to unsolicited calls, may, by serving international clients, realize that there are opportunities abroad and move from PC2 to PC1, embracing internationalization. As a summary, we show all the focal firms and their corresponding strategic type in Table 5.

\section{INSERT TABLE 5 HERE}

\subsection{Managerial implications}

Our findings have some interesting managerial implications. We show that there are different typologies of internationalization, where the motives link to the possible evolutionary trajectory of the firm after internationalization. We discuss that there may be different performance consequences for this - many of which relate to learning opportunities intertwined with the focal early internationalization trajectories. This is important for Latin America, where small, often protected markets, limit opportunities for business to grow (Ciravegna et al., 2014).

Another important point to consider is the triggers to change the strategic type of internationalization that we have covered in our study. What are the critical incidents that make a firm change from 'serendipitous mode' to more 'entrepreneurial' or 'planning mode'? Our longitudinal study shows changes along the internationalization pathway. It would make sense for entrepreneurs to benchmark older companies and outcomes as this could provide heuristic value for their decision-making. Another important managerial implication is that 
internationalizing provides firms with opportunities to not only expand their business, but also to change their business model, and often, to learn.

\subsection{Limitations and further research}

An important limitation of our study is that one might need more variables to acquire a richer understanding of the drivers and outcomes of the timing of internationalization in the Latin American context. Further, it would be interesting to study the effect of home country features, as early internationalization exposes firms to different customers, competitors, partners, suppliers, institutions, and knowledge in a short period of time. Home country institutions and characteristics, other than size, may affect the strategy of the firm (Brenes, Ciravegna, \& Pichardo, 2018; Deng, Jean, \& Sinkovics, in press). In order to better study the impact of, for example, domestic market size, it would be interesting to examine firms based in a broader range of countries, and encompassing a broader range of industries. In particular, it would be interesting to examine whether the key industries of Latin America, that is, extractive industries, agribusiness, and tourism, behave differently from manufacturing, IT, and other services, such as retail. Nonetheless, we believe that this study provides an interesting insight into the typologies of internationalization timing and outcomes in Latin America, suggesting avenues for further research and ways in which the empirical context fits with the tenets of different literatures. 


\section{References}

Acedo, F. J., \& Jones, M. V. (2007). Speed of internationalization and entrepreneurial cognition: Insights and a comparison between international new ventures, exporters and domestic firms. Journal of World Business, 42(3), 236-252.

Aldenderfer, M. S. \& Blashfield, R. K. (1984). Cluster analysis: Quantitative applications in the social sciences. Beverly Hills, CA: Sage Publications.

Andersson, S. (2000). The internationalization of the firm from an entrepreneurial perspective. International Studies of Management \& Organization, 30(1), 63-92.

Autio, E., Sapienza, H. J., \& Almeida, J. G. (2000). Effects of age at entry, knowledge intensity, and imitability on international growth. Academy of Management Journal, 43(5), 909924.

Bell, J., McNaughton, R., \& Young, S. (2001). 'Born-again global' firms: An extension to the 'born global' phenomenon. Journal of International Management, 7(3), 173-189.

Bell, J., McNaughton, R., Young, S., \& Crick, D. (2003). Towards an integrative model of small firm internationalisation. Journal of International Entrepreneurship, 1(4), 339-362.

Benito, G. R., \& Welch, L. S. (1997). De-internationalization. MIR: Management International Review, 37(Special Issue), 7-25.

Boso, N., Story, V. M., \& Cadogan, J. W. (2013). Entrepreneurial orientation, market orientation, network ties, and performance: Study of entrepreneurial firms in a developing economy. Journal of Business Venturing, 28(6), 708-727.

Brenes, E. R., Camacho, A. R., Ciravegna, L., \& Pichardo, C. A. (2016). Strategy and innovation in emerging economies after the end of the commodity boom-Insights from Latin America. Journal of Business Research, 69(10), 4363-4367.

Brenes, E. R., Ciravegna, L., \& Pichardo, C. A. (2018). Managing institutional voids: A configurational approach to understanding high performance antecedents. Journal of Business Research. http://dx.doi.org/10.1016/j.jbusres.2018.03.022.

CAMTIC (2008). Database of the Costa Rican information and telecommunication technologies producers, internal document. San José, Costa Rica: CAMTIC.

Casillas, J. C., \& Acedo, F. J. (2013). Speed in the internationalization process of the firm. International Journal of Management Reviews, 15(1), 15-29.

Cavusgil, S. T., \& Knight, G. (2015). The born global firm: An entrepreneurial and capabilities perspective on early and rapid internationalization. Journal of International Business Studies, 46(1), 3-16.

Chandra, Y., Styles, C., \& Wilkinson, I. (2009). The recognition of first time international entrepreneurial opportunities: Evidence from firms in knowledge-based industries. International Marketing Review, 26(1), 30-61.

Ciravegna, L. (2012). Promoting Silicon Valleys in Latin America: Lessons from Costa Rica. New York: Routledge.

Ciravegna, L., Lopez, L., \& Kundu, S. (2014). Country of origin and network effects on internationalization: A comparative study of SMEs from an emerging and developed economy. Journal of Business Research, 67(5), 916-923.

Coviello, N. (2015). Re-thinking research on born globals. Journal of International Business Studies, 46(1), 17-26. 
Deng, Z., Jean, R.-J. B, \& Sinkovics, R. R. (in press). Rapid expansion of international new ventures across institutional distance. Journal of International Business Studies. Online, available at: https://doi.org/10.1057/s41267-017-0108-6.

Dimitratos, P., Johnson, J. E., Plakoyiannaki, E., \& Young, S. (2016). SME internationalization: How does the opportunity-based international entrepreneurial culture matter? International Business Review, 25(6), 1211-1222.

Dowling, G. R., \& Midgley, D. F. (1988). Identifying the coarse and fine structures of market segments. Decision Sciences, 19(4), 830-847.

Dunteman, G. H. (1989). Principal components analysis (Quantitative applications in the social sciences series). Newbury Park, CA: Sage Publications.

Ellis, P. D. (2011). Social ties and international entrepreneurship: Opportunities and constraints affecting firm internationalization. Journal of International Business Studies, 42(1), 99127.

Freeman, S., \& Cavusgil, S. T. (2007). Toward a typology of commitment states among managers of born-global firms: A study of accelerated internationalization. Journal of International Marketing, 15(4), 1-40.

Ganesan, V., \& Samii, M. (2016). Internationalization and longevity of small-and medium-sized software firms. Journal of Small Business \& Entrepreneurship, 27(6), 537-555.

Hagen, B., Zucchella, A., Larimo, J., \& Dimitratos, P. (2017). A taxonomy of strategic postures of international SMEs. European Management Review, 14(3), 265-285.

Hartigan, J. (1975). Clustering algorithms. New York: John Wiley.

Hennart, J. F. (2014). The accidental internationalists: A theory of born globals. Entrepreneurship Theory and Practice, 38(1), 117-135.

Hilmersson, M. \& Johanson, M. (2016). Speed of SME internationalization and performance. Management International Review, 56(1), 67-94.

Javalgi, R. R. G., \& Todd, P. R. (2011). Entrepreneurial orientation, management commitment, and human capital: The internationalization of SMEs in India. Journal of Business Research, 64(9), 1004-1010.

Johanson, J., \& Vahlne, J. E. (1990). The mechanism of internationalization, International Marketing Review, 7(4), 11-24.

Johanson, J., \& Vahlne, J. E. (2009). The Uppsala internationalization process model revisited: From liability of foreignness to liability of outsidership. Journal of International Business Studies, 40(9), 1411-1431.

Johanson, J., \& Wiedersheim-Paul, F. (1975). The internationalization of the firm-Four Swedish cases. Journal of Management Studies, 12(3), 305-323.

Jolliffe, I. T. (1986). Principal component analysis. New York: Springer-Verlag.

Jones, M. V., Coviello, N., \& Tang, Y. K. (2011). International entrepreneurship research (19892009): A domain ontology and thematic analysis. Journal of Business Venturing, 26(6), 632-659.

Knight, G. A., \& Cavusgil, S. T. (2004). Innovation, organizational capabilities, and the bornglobal firm. Journal of International Business Studies, 35(2), 124-141.

Kontinen, T., \& Ojala, A. (2011). Network ties in the international opportunity recognition of family SMEs. International Business Review, 20(4), 440-453.

Kuivalainen, O., Saarenketo, S., \& Puumalainen, K. (2012). Start-up patterns of internationalization: A framework and its application in the context of knowledgeintensive SMEs. European Management Journal, 30(4), 372-385. 
Kuivalainen, O., Sundqvist, S., \& Servais, P. (2007). Firms’ degree of born-globalness, international entrepreneurial orientation and export performance. Journal of World Business, 42(3), 253-267.

Leonidou, L. C. (1995). Export stimulation research: Review, evaluation and integration. International Business Review, 4(2), 133-156.

Leonidou, L. C., Katsikeas, C. S., Palihawadana, D., \& Spyropoulou, S. (2007). An analytical review of the factors stimulating smaller firms to export: Implications for policy-makers. International Marketing Review, 24(6), 735-770.

Lopez, L. E., Kundu, S. K., \& Ciravegna, L. (2009). Born global or born regional? Evidence from an exploratory study in the Costa Rican software industry. Journal of International Business Studies, 40(7), 1228-1238.

Malhotra, N. K., Agarwal, J., \& Ulgado, F. M. (2003). Internationalization and entry modes: A multitheoretical framework and research propositions. Journal of International Marketing, 11(4), 1-31.

Mathews, J.A., \& Zander, I. (2007). The international entrepreneurial dynamics of accelerated internationalization. Journal of International Business Studies, 38(3), 387-403.

McDougall, P. P., \& Oviatt, B. M. (2000). International entrepreneurship: The intersection of two research paths. Academy of Management Journal, 43(5), 902-906.

Moen, Ø., \& Servais, P. (2002). Born global or gradual global? Examining the export behavior of small and medium-sized enterprises. Journal of International Marketing, 10(3), 49-72.

Monaghan, S., \& Tippmann, E. (2018). Becoming a multinational enterprise: Using industry recipes to achieve rapid multinationalization. Journal of International Business Studies, 49(4), 473-495.

Mudambi, R., \& Zahra, S.A. (2007). The survival of international new ventures. Journal of International Business Studies, 38(2), 333-352.

Ogram, E. W. (1982). Exporters and non-exporters: A profile of small manufacturing firms in Georgia. In M. R. Czinkota, \& G. Tesar (Eds.), Export management: An international context (pp. 70-84). New York: Praeger Publishers.

Ojala, A. (2009). Internationalization of knowledge-intensive SMEs: The role of network relationships in the entry to a psychically distant market. International Business Review, 18(1), 50-59.

Oviatt, B. M., \& McDougall, P. P. (1994). Toward a theory of international new ventures. Journal of International Business Studies, 25(1), 45-64.

Oviatt, B. M., \& McDougall, P. P. (2005). Defining international entrepreneurship and modeling the speed of internationalization. Entrepreneurship Theory and Practice, 29(5), 537-554.

Porter, M. E. (1998). Clusters and the new economies of competition. Harvard Business Review, 76, 77-90.

Reid, S. D. (1981). The decision-maker and export entry and expansion. Journal of International Business Studies, 12(2), 101-112.

Reuber, A. R., Dimitratos, P., \& Kuivalainen, O. (2017). Beyond categorization: New directions for theory development about entrepreneurial internationalization. Journal of International Business Studies, 48(4), 411-422.

Schwens, C., Zapkau, F. B., Bierwerth, M., Isidor, R., Knight, G., \& Kabst, R. (2017). International entrepreneurship: A meta-analysis on the internationalization and performance relationship. Entrepreneurship Theory and Practice, DOI: 10.1111/etap.12280 
Shepherd D.A., Patzelt H. (2017). Researching entrepreneurial decision making. In Trailblazing in entrepreneurship (pp. 257-285). Cham: Switzerland: Palgrave Macmillan.

Shrader, R. C., Oviatt, B. M., \& McDougall, P. P. (2000). How new ventures exploit trade-offs among international risk factors: Lessons for the accelerated internationalization of the 21st century. Academy of Management Journal, 43(6), 1227-1247.

Sommer, L. (2010). Internationalization processes of small-and medium-sized enterprises-A matter of attitude? Journal of International Entrepreneurship, 8(3), 288-317.

Terjesen, S., Hessels, J., \& Li, D. (2016). Comparative international entrepreneurship: A review and research agenda. Journal of Management, 42(1), 299-344.

Vanninen, H., Kuivalainen, O., \& Ciravegna, L. (2017). Rapid multinationalization: Propositions for studying born micromultinationals. International Business Review, 26(2), 365-379.

Verbeke, A., \& Kano, L. (2016). An internalization theory perspective on the global and regional strategies of multinational enterprises. Journal of World Business, 51(1), 83-92.

Verbeke, A., \& Ciravegna, L. (2018). International entrepreneurship research versus international business research: A false dichotomy?. Journal of International Business Studies 49(4): 387-394

Villalobos, V., \& Monge-González, R. (2011). Costa Rica’s efforts toward an innovation-driven economy: The role of the ICT sector. The Global Information Technology Report 20102011, (pp. 119-126). Geneva, Switzerland: World Economic Forum.

Vissak, T. \& Francioni, B. (2013). Serial nonlinear internationalization in practice: A case study. International Business Review, 22(6), 951-962.

Welch, C. L. \& Welch, L. S. (2009). Re-internationalisation: Exploration and conceptualisation. International Business Review, 18(6), 567-577.

Welch, L.S., \& Luostarinen, R. (1988). Internationalization: Evolution of a concept. Journal of General Management, 14(2), 36-64.

Westhead, P., Wright, M., \& Ucbasaran, D. (2001). The internationalization of new and small firms: A resource-based view. Journal of Business Venturing, 16(4), 333-358.

Wiedersheim-Paul, F., Olson, H. C., \& Welch, L. S. (1978). Pre-export activity: The first step in internationalization. Journal of International Business Studies, 9(1), 47-58.

Zahra, S. A. (2005). A theory of international new ventures: A decade of research. Journal of International Business Studies, 36(1), 20-28.

Zahra, S. A., \& George, G. (2002). International entrepreneurship: The current status of the field and future research agenda. In M. A. Hitt, R. D. Ireland, S. M. Camp, \& D. L. Sexton (Eds.), Strategic entrepreneurship: Creating a new mindset. (pp. 255-288). Oxford, UK: Blackwell Publishers.

Zahra, S. A., Korri, J. S., \& Yu, J. (2005). Cognition and international entrepreneurship: Implications for research on international opportunity recognition and exploitation. International Business Review, 14(2), 129-146.

Zahra, S. A., Neubaum, D. O., \& Huse, M. (1997). The effect of the environment on export performance among telecommunications new ventures. Entrepreneurship Theory and Practice, 22(1), 25-46. 
Figure 1. Conceptual model

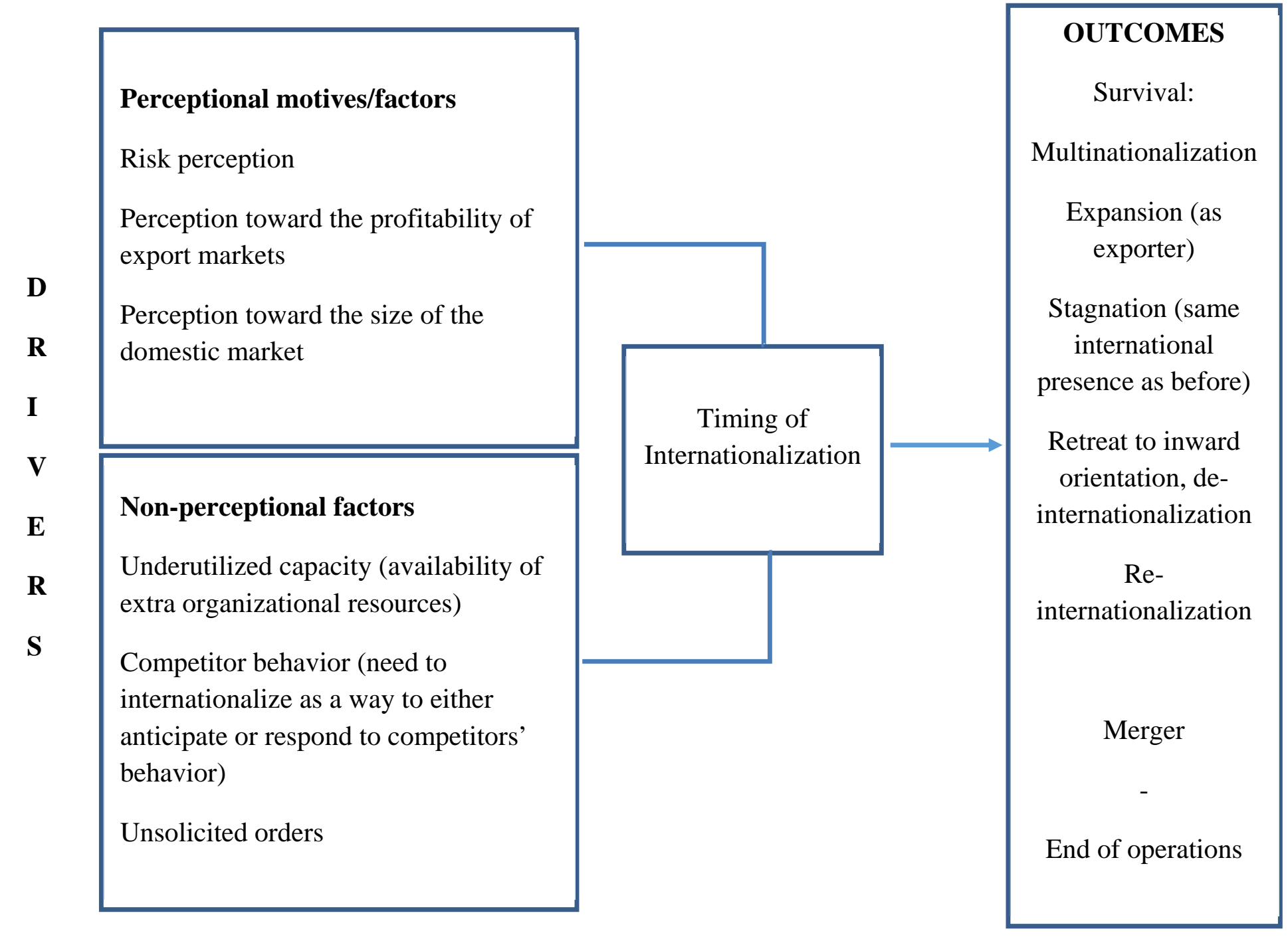




\begin{tabular}{|c|c|c|c|c|c|c|c|}
\hline$n=29$ & $\begin{array}{l}\text { Reception of } \\
\text { unsolicited } \\
\text { orders }\end{array}$ & $\begin{array}{l}\text { Existence of } \\
\text { unused spare } \\
\text { capacity }\end{array}$ & $\begin{array}{l}\text { Operating in } \\
\text { small market } \\
\text { size }\end{array}$ & $\begin{array}{l}\text { Exports or } \\
\text { competitive } \\
\text { behavior by } \\
\text { competitor }\end{array}$ & $\begin{array}{l}\text { Time from } \\
\text { firm inception } \\
\text { to first export }\end{array}$ & $\begin{array}{l}\text { Internatio } \\
\text { nal market } \\
\text { risk }\end{array}$ & $\begin{array}{l}\text { Internatio } \\
\text { nal } \\
\text { markets } \\
\text { profit }\end{array}$ \\
\hline $\begin{array}{c}\text { Reception of } \\
\text { unsolicited orders }\end{array}$ & 1 & 0.06 & 0.05 & $-0.430 *$ & 0.01 & 0.25 & 0.00 \\
\hline $\begin{array}{c}\text { Existence of } \\
\text { underutilized } \\
\text { capacity }\end{array}$ & & 1 & $-0.360 \S$ & -0.09 & 0.00 & -0.25 & -0.19 \\
\hline Small market size & & & 1 & 0.02 & -0.01 & 0.05 & 0.17 \\
\hline $\begin{array}{l}\text { Exports by } \\
\text { competitor }\end{array}$ & & & & 1 & -0.01 & -0.02 & -0.03 \\
\hline Time to first export & & & & & 1 & 0.08 & -0.21 \\
\hline $\begin{array}{c}\text { International } \\
\text { market risk }\end{array}$ & & & & & & 1 & 0.44 \\
\hline$* p<0.05 ; \S p<0.1$ & & & & & & & \\
\hline
\end{tabular}


Table 2: Principal Component Analysis of internationalization timing drivers

PRINCIPAL COMPONENTS

\begin{tabular}{lccccccc}
\cline { 2 - 7 } Variables & PC1 & PC2 & PC3 & PC4 & PC5 & PC6 & PC7 \\
\cline { 2 - 8 } Perception of Risk & 0.60 & 0.30 & -0.60 & -0.02 & -0.27 & -0.04 & 0.35 \\
Perception of Profitability & 0.68 & -0.02 & -0.46 & -0.38 & 0.29 & -0.02 & -0.30 \\
Small Market Size & 0.66 & -0.28 & 0.39 & 0.13 & -0.03 & -0.57 & 0.01 \\
Underutilized Capacity & -0.63 & 0.36 & 0.06 & -0.59 & 0.03 & -0.33 & 0.12 \\
Competitor Behavior & -0.43 & -0.59 & -0.42 & -0.04 & -0.48 & -0.15 & -0.20 \\
Unsolicited Orders & 0.25 & 0.78 & 0.29 & 0.00 & -0.41 & 0.03 & -0.27 \\
Time to First Export & -0.44 & 0.47 & -0.46 & 0.47 & 0.22 & -0.30 & -0.11 \\
Eigenvalue & 2.10 & 1.48 & 1.19 & 0.73 & 0.60 & 0.55 & 0.35 \\
Individual \% & 29.99 & 21.18 & 17.03 & 10.4 & 8.59 & 7.8 & 5 \\
Cumulative \% & 29.99 & 51.17 & 68.21 & 78.61 & 87.2 & 95 & 100 \\
\hline
\end{tabular}

Table 3: Cluster means of sample scores in principal components

\begin{tabular}{cccc}
\hline Composite & Entrepreneurial & Serendipitous & Strategic \\
\hline PC1 & 0.40 & -2.51 & -0.33 \\
PC2 & -0.10 & 1.24 & -0.08 \\
PC3 & -0.38 & -1.53 & 1.28 \\
\hline $\begin{array}{c}\text { Number of } \\
\text { firms }\end{array}$ & 19 & 2 & 8 \\
\hline
\end{tabular}


Table 4: Outcomes of internationalization timing

\begin{tabular}{|c|c|c|c|c|c|}
\hline & $\begin{array}{l}\text { Drivers of } \\
\text { internationalization }\end{array}$ & Timing & $\begin{array}{l}\text { Geographic } \\
\text { Scope }\end{array}$ & Product type & Outcomes \\
\hline $\begin{array}{l}\text { PC1: } \\
\text { Entrepreneurial } \\
\text { internationalization }\end{array}$ & $\begin{array}{l}\text { Entrepreneurial } \\
\text { perceptions } \\
\text { Size of domestic } \\
\text { economy } \\
\text { Unsolicited orders } \\
\text { Capacity }\end{array}$ & Early & $\begin{array}{l}\text { Regional, } \\
\text { markets where } \\
\text { entrepreneur has } \\
\text { contacts }\end{array}$ & $\begin{array}{l}\text { Products } \\
\text { developed with } \\
\text { regional markets } \\
\text { in mind or } \\
\text { adapted from } \\
\text { local to regional }\end{array}$ & $\begin{array}{l}\text { Development into MNE to exploit } \\
\text { market-seeking or efficiency- } \\
\text { seeking opportunities. PC1 - PC3 } \\
\text { transformation } \\
\text { Acquisition by foreign partners } \\
\text { Re-entrenchment into domestic } \\
\text { market after initial expansion; } \\
\text { change of business model; re- } \\
\text { internationalization }\end{array}$ \\
\hline $\begin{array}{l}\text { PC2: } \\
\text { Serendipitous } \\
\text { internationalization }\end{array}$ & $\begin{array}{l}\text { Unsolicited orders } \\
\text { Capacity }\end{array}$ & Late & $\begin{array}{l}\text { Mainly regional, } \\
\text { depending on } \\
\text { unsolicited orders }\end{array}$ & $\begin{array}{l}\text { Domestic } \\
\text { product adapted } \\
\text { for export }\end{array}$ & $\begin{array}{l}\text { Re-entrenchment into domestic } \\
\text { market } \\
\text { Stagnation, failure } \\
\text { Continuation of exports and } \\
\text { internationalization; learning from } \\
\text { international markets. Attitude } \\
\text { change, PC2 - PC1 transformation }\end{array}$ \\
\hline $\begin{array}{l}\text { PC3: } \\
\text { Strategic } \\
\text { internationalization }\end{array}$ & $\begin{array}{l}\text { Strategic plan } \\
\text { Size of domestic } \\
\text { economy }\end{array}$ & Early & Global & $\begin{array}{l}\text { Niche products } \\
\text { aimed at } \\
\text { international } \\
\text { markets }\end{array}$ & $\begin{array}{l}\text { Start as MNE } \\
\text { Development into MNE with } \\
\text { functions located according to the } \\
\text { country-specific advantages } \\
\text { Internal problems, stagnation }\end{array}$ \\
\hline
\end{tabular}


Table 5: Firms in the sample and information about them

\begin{tabular}{|c|c|c|c|c|c|c|c|c|}
\hline Name & $\begin{array}{l}\text { Cluster loads on } \\
\text { factor }\end{array}$ & $\begin{array}{l}\text { Year of } \\
\text { foundation }\end{array}$ & $\begin{array}{l}\text { Years } \\
\text { between } \\
\text { inception } \\
\text { and first } \\
\text { foreign } \\
\text { market } \\
\text { entry }\end{array}$ & $\begin{array}{l}\text { Export } \\
\text { Intensity } \\
\text { (\% total } \\
\text { average } \\
\text { yearly } \\
\text { sales) }\end{array}$ & $\begin{array}{l}\text { Nominal } \\
\text { compound } \\
\text { annual } \\
\text { growth } \\
\text { rate } \\
\text { (CAGR) of } \\
\text { sales over } \\
\text { years } \\
\text { exporting } \\
\text { (a) }\end{array}$ & $\begin{array}{l}\text { Employees } \\
\text { at time of } \\
\text { first data } \\
\text { collection } \\
\text { (b) }\end{array}$ & $\begin{array}{l}\text { Self- } \\
\text { assessed } \\
\text { future } \\
\text { export } \\
\text { activity as } \\
\text { percentag } \\
\text { e of sales } \\
\text { (c) }\end{array}$ & Outcome \\
\hline 1 & PC1 & 1987 & 6 & $61 \%$ & $55 \%$ & $100+$ & $75 \%$ & Active \\
\hline 2 & PC1 & 1996 & 0 & $81 \%$ & $35 \%$ & $51-100$ & $75 \%$ & Active \\
\hline DELTA & $\begin{array}{l}\text { PC 1- } \\
\text { Entrepreneurial } \\
\text { Internationalizati } \\
\text { on }\end{array}$ & 1997 & 3 & $20 \%$ & $23 \%$ & $0-10$ & $25 \%$ & $\begin{array}{l}\text { Changed name } \\
\text { and business } \\
\text { model }\end{array}$ \\
\hline ALFA & PC 1 & 1999 & 4 & $15 \%$ & $347 \%$ & $26-50$ & $75 \%$ & $\begin{array}{l}\text { Active, became } \\
\text { a multinational, } \\
\text { with operations } \\
\text { in all largest } \\
\text { markets of Latin } \\
\text { America }\end{array}$ \\
\hline 8 & PC1 & 1982 & 2 & $58 \%$ & $26 \%$ & $11-25$ & $75 \%$ & Active \\
\hline 9 & PC1 & 1991 & 6 & $33 \%$ & $44 \%$ & $11-25$ & $50 \%$ & Active \\
\hline 10 & PC1 & 1987 & 13 & $50 \%$ & $172 \%$ & $51-100$ & $75 \%$ & Active \\
\hline 11 & PC1 & 1995 & 4 & $77 \%$ & $612 \%$ & $0-10$ & $75 \%$ & Active \\
\hline BETA & PC 1 & 1996 & 5 & $77 \%$ & $3751 \%$ & $51-100$ & $75 \%$ & $\begin{array}{l}\text { Active, became } \\
\text { a multinational } \\
\text { opening } \\
\text { subsidiaries in } \\
\text { low-cost } \\
\text { locations in } \\
\text { Latin America }\end{array}$ \\
\hline 14 & PC-1 & 2000 & 2 & $10 \%$ & $141 \%$ & $11-25$ & $25 \%$ & $\begin{array}{l}\text { Exited from } \\
\text { business }\end{array}$ \\
\hline
\end{tabular}




\begin{tabular}{|c|c|c|c|c|c|c|c|c|}
\hline 16 & PC1 & 1994 & 2 & $80 \%$ & $29 \%$ & $51-100$ & $50 \%$ & Active \\
\hline 18 & PC1 & 2002 & 0 & $100 \%$ & $166 \%$ & $0-10$ & $100 \%$ & Active \\
\hline 19 & PC1 & 2001 & 4 & $0 \%$ & $800 \%$ & $11-25$ & $50 \%$ & $\begin{array}{l}\text { Exited from } \\
\text { business }\end{array}$ \\
\hline GAMMA & PC 1 & 1992 & 2 & $\begin{array}{l}100 \% \text { (up } \\
\text { to when it } \\
\text { existed } \\
\text { under its } \\
\text { name) }\end{array}$ & $38 \%$ & $100+$ & $100 \%$ & $\begin{array}{l}\text { Acquired by a } \\
\text { European client }\end{array}$ \\
\hline 23 & PC1 & 1988 & 7 & $11 \%$ & $30 \%$ & $11-25$ & $50 \%$ & Active \\
\hline 24 & PC1 & 2001 & 4 & $0 \%$ & $350 \%$ & $0-10$ & $100 \%$ & $\begin{array}{l}\text { Exited from } \\
\text { business }\end{array}$ \\
\hline 25 & PC1 & 1999 & 3 & $13 \%$ & $96 \%$ & $51-100$ & $25 \%$ & Active \\
\hline 27 & PC1 & 2001 & 0 & $20 \%$ & $26 \%$ & $11-25$ & $75 \%$ & Active \\
\hline 29 & PC1 & 1996 & 7 & $18 \%$ & $276 \%$ & $0-10$ & $100 \%$ & Active \\
\hline MUDI & $\begin{array}{l}\text { PC2 - Reactive } \\
\text { internationalizati } \\
\text { on }\end{array}$ & 1985 & 17 & $5 \%$ & $188 \%$ & $51-100$ & $<25 \%$ & $\begin{array}{l}\text { Exited from } \\
\text { business }\end{array}$ \\
\hline JUDI & PC 2 & 1987 & 10 & $40 \%$ & $12 \%$ & $0-10$ & $75 \%$ & $\begin{array}{l}\text { Active, } \\
\text { increased } \\
\text { export intensity } \\
\text { from from } 40 \% \\
\text { to } 70 \% \text { between } \\
2009 \text { and } 2017\end{array}$ \\
\hline SOFT & $\begin{array}{l}\text { PC } 3 \text { - Strategic } \\
\text { internationalizati } \\
\text { on }\end{array}$ & 1993 & 2 & $100 \%$ & $54 \%$ & $51-100$ & $100 \%$ & $\begin{array}{l}\text { Acquired by an } \\
\text { American client }\end{array}$ \\
\hline ETA & PC 3 & 1992 & 1 & $100 \%$ & $14 \%$ & $0-10$ & $25 \%$ & $\begin{array}{l}\text { Active, became } \\
\text { a multinational, } \\
\text { sells most } \\
\text { output via its } \\
\text { subsidiary in the } \\
\text { US }\end{array}$ \\
\hline & PC3 & 1997 & 0 & $15 \%$ & $17 \%$ & $11-25$ & $50 \%$ & $\begin{array}{l}\text { Exited from } \\
\text { business }\end{array}$ \\
\hline
\end{tabular}




\begin{tabular}{|c|c|c|c|c|c|c|c|c|}
\hline SIGMA & PC 3 & 1986 & 2 & $72 \%$ & $37 \%$ & $100+$ & $75 \%$ & $\begin{array}{l}\text { Active, but } \\
\text { website not } \\
\text { updated and } \\
\text { not hiring }\end{array}$ \\
\hline 20 & PC3 & 1998 & 0 & $42 \%$ & $13 \%$ & $11-25$ & $50 \%$ & Active \\
\hline 21 & PC3 & 1995 & 4 & $47 \%$ & $31 \%$ & $26-50$ & $50 \%$ & Active \\
\hline 26 & PC3 & 2000 & 1 & $100 \%$ & $1945 \%$ & $11-25$ & $75 \%$ & Active \\
\hline 28 & PC3 & 1998 & 2 & NA & N.A. & $11-25$ & $75 \%$ & Active \\
\hline NOTES & & & & & & & & \\
\hline
\end{tabular}

(a) Nominal compounded annual growth rate of sales since started exported is given here as a reference only. Note that some firms started from a very small base and grew over a short period, hence show large values

(b) Size in number of employees is provided in ranges as shown

(c) Respondents were asked to provide an assessment of future export performance by estimating what percentage of total output would be designated to exporting in 5 years' time 